\title{
Rainbow Valley as Embodied Heaven: Initial Explorations into L.M. Montgomery's Spirituality in Fiction
}

DOI

https://doi.org/10.32393/jlmms/2020.0003

Published on

Mon, 05/11/2020 - 13:27

Intriguingly, L.M. Montgomery's generally realistic fiction is filled with fantastic elements. This article argues that by following Montgomery into the heavenly fairyland of Rainbow Valley, readers can discern a joyful, creative, imaginative, and integrated image of spiritual life in the conversations, the characters, and the magic valley itself.

\section{Introduction: Passport to the Geography of Fairyland}

At the romantic climax of Kevin Sullivan's miniseries adaptation Anne of Green Gables: The Sequel, there is an intriguing interpretation of Anne. Anne's reconciliation with Gilbert is tied up with her rejection of fairy tales and romantic, imaginative worlds in favour of realistic fiction. Anne gives her real-life story collection to Gilbert on his recovery bed, saying, "I wrote about Avonlea, just as you said I should, without any highfalutin mumbo-jumbo." 1 Sullivan's Gilbert reflects the kind of advice Anne gets from her neighbour, James A. Harrison, where she is advised to "Cut out all those flowery passages" and "high-flown language," and to turn instead to writing what she knows. 2 


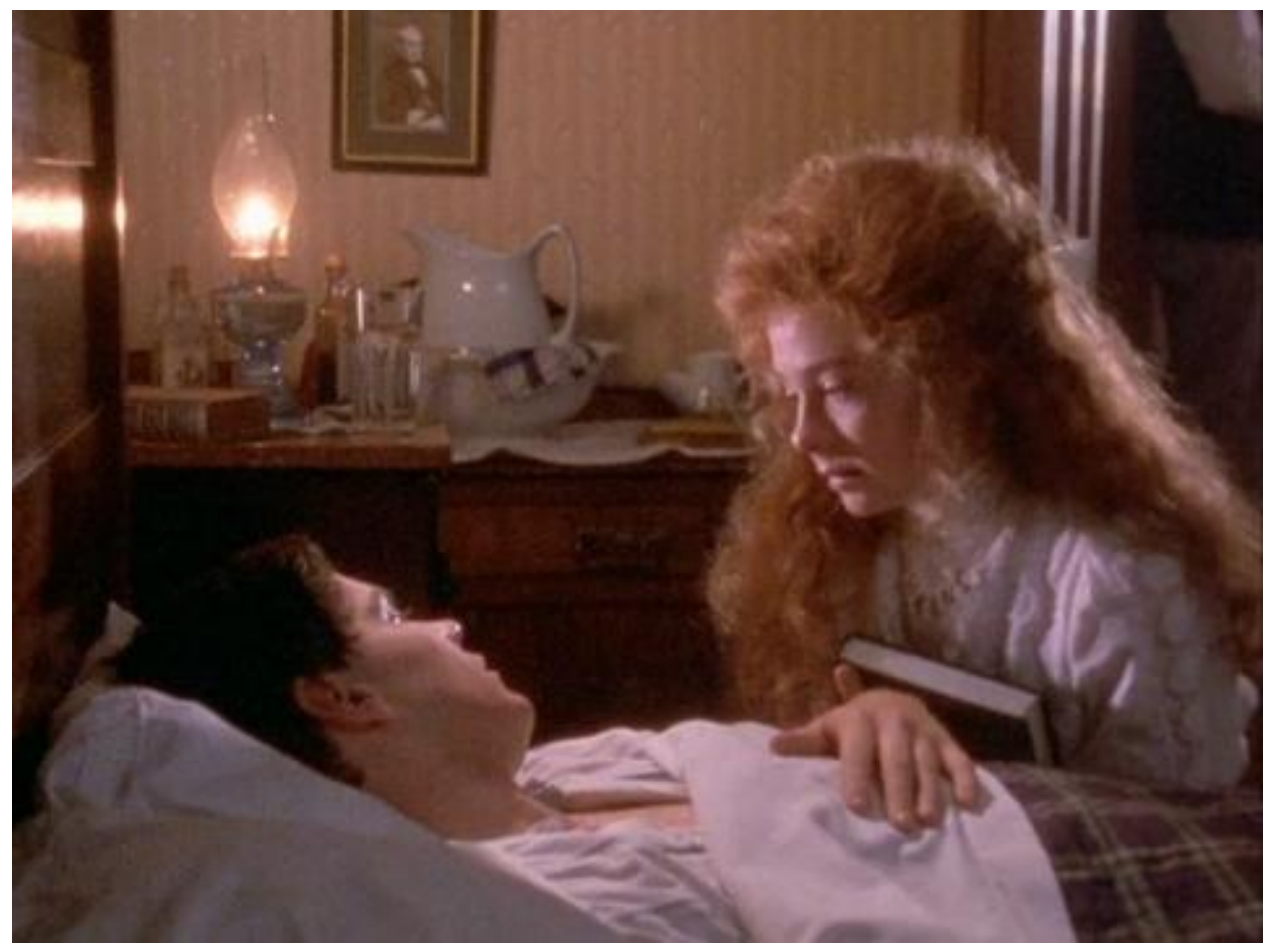

Still from Sullivan Film's Anne of Green Gables: The Sequel (1:47). 1987.

Anne's turn to realism, however, is not what readers see in the books. In Montgomery's original fiction, Anne's first editor-reviewed publication is "a most interesting dialogue between the asters and the sweet peas and the wild canaries in the lilac bush and the guardian spirit of the garden" that she had written while stuck in the collapsed roof of the Copp duck house-really "just a string of fancies," Anne confesses. 3 As a child, Anne discovers Avonlea's fantastic elements in the "glittering fairy arch" of Lover's Lane $\underline{4}$ and the spring by the log bridge, which she names "the Dryad's Bubble." $\underline{5}$ As an adult, Anne still sees in Rainbow Valley's Four Winds Harbour a "fountain of old romance" in "the magic valley" that is reminiscent of the Dryad's Bubble. 6 Anne still dreams "incorrigible dreams" $\underline{7}$ and still basks in the "fairy flicker" of a driftwood fire. 8 Though in Rainbow Valley and Rilla of Ingleside the narrative focus shifts away from Anne, her imaginative connection to fairy realms remains, especially as these imaginative worlds intersect with the natural world of beauty. 


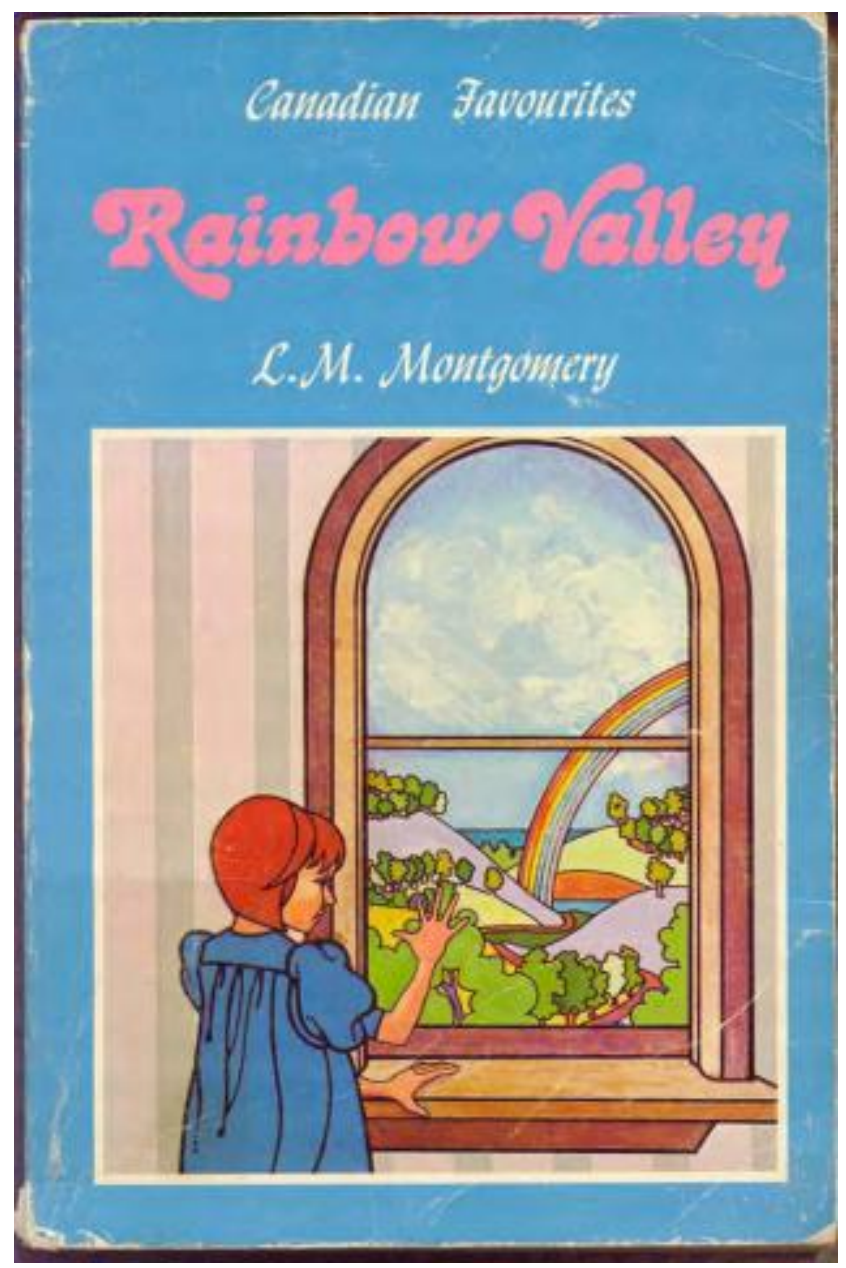

Book cover of Rainbow Valley. 1973. KindredSpaces.ca, 162 RV-MS.

Moreover, according to Anne's close intimate in the adult books, Miss Cornelia, Anne's imaginative quality is passed from mother to child, and especially to Walter. $\underline{9}$ The poet Walter is noted for his capacity for envisioning heaven as both a naturalistic and fantastic realm, one coloured like the sunset and filled with sapphire towers, rainbow domes, buildings, and streets of gold and diamonds surrounding light-kissed crystal fountains-a place where "everywhere the asphodel blooms." 10 In The Blythes Are Quoted readers learn that Anne has been writing poetry her whole life. This poetry is shot through with fairy-tale references that provide central organizing images for Anne and Walter's nostalgia, romance, grief, and loss. Some of these references to fairyland are no doubt about the passing of childhood:

Be a girl I leave her, too, All the fairy dreams I knew, All my fancies, all the hosts 
Of my little friendly ghosts.11

But fey elements are not all nostalgic, including references to Walter's own poetic imagination.

I walked with Wind of Autumn across the upland airy,

Where canny eyes might hope to spy the little Men in Green,

By road of firs that should have led right on to land of faery,

Enchanted lands the sun and moon between.12

In particular, there is a dark foreboding in some faërie 13 references as they are bound up with Walter's fate. In his visions of the Pied Piper that emerge in Rainbow Valley and are fulfilled in Rilla of Ingleside, Walter's death in World War I is the result of going to the perilous land of faërie. Walter embodies not merely a poetic and imaginative inheritance from Anne but also the realization of romantic dreams.

Finally, The Blythes Are Quoted shows an Anne whose work as a writer has, throughout her whole life, continued to wander on the paths "Where the fairy folk of the upland dwell." 14 Sullivan's romantic conclusion to the 1980 s set of miniseries, no doubt satisfying to many viewers, has a limited view of romance and reveals an often-overlooked tension in Montgomery's work. Montgomery is, after all, a mimetic writer, but one who creates characters who not only walk but dance and play on the road that leads "to the gateways of the west," 15 where myth, legend, romance, and fantasy dwell.

This tension between realism and fantasyland is particularly intriguing when it comes to the embedded spirituality in Montgomery's stories as they are revealed in faërie elements. Montgomery wrote in her 4 April 1899 journal entry, "I like realistic and philosophical novels in spells, but for pure, joyous, undiluted delight give me romance. I always reveled in fairy tales." 16 "Fairy tale" in apposition to "romance" reminds us of the oft-forgotten element of the word "romance" in Montgomery's world. "Romance" does not merely mean love interest or Anne's desire for the tragic-beautiful, but includes critical essential elements of what we now call fantasy, made up of tales of adventure and stories about fairy folk. 


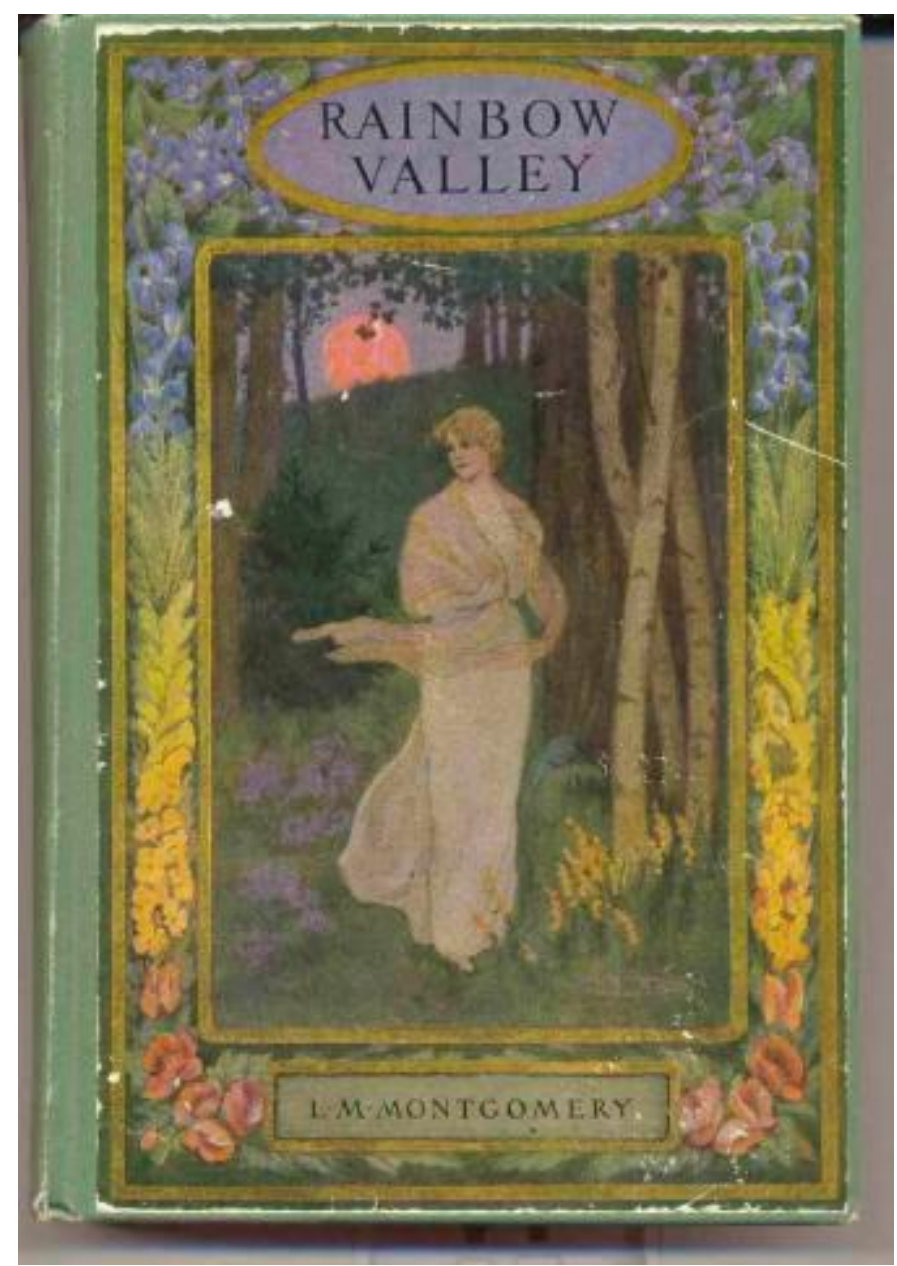

Book cover of Rainbow Valley. 1919. KindredSpaces.ca, 539 RV-MS-1ST.

Among the tensions that Montgomery exploits, the "palpable" tension of "realism and romance" is a part of what drew Elizabeth Rollins Epperly to write a book-length study of Montgomery's works. Epperly's writing about "romance" in The Fragrance of Sweet-Grass: L.M. Montgomery's Heroines and the Pursuit of Romance is polemical as she attempts to recover a critical reading of Montgomery's works while resisting reductive or dismissive approaches that include "overt and covert assumptions about romance." 17 In carving out this critical path, Epperly chooses to limit the use of "romance" and "romantic" to the popular sense, while trying to leave an opening for the reader to imagine the deeper literary resonances.18 Epperly thus includes elements of chivalric, heroic, Wordsworthian, and Victorian romance in her analysis, but focuses less on supernatural and faërie elements of romantic traditions. Thus, in her analysis, "fairy tale" is typically treated as a kind of heroic love story. For example, Epperly reads the John Meredith-Rosemary West thread in Rainbow Valley as a fairy tale with chivalric notes.19 This approach to romance takes a darker 
tone in Epperly's analysis of the Emily cycle, with some suggestions of faërie beyond the everyday and literary realms of romantic love.20 Epperly admits in her 2014 preface that she might define "romance" differently today. 21

Following Epperly's instinct to open the word "romance" to non-mimetic elements, this article explores romantic images from the worlds of fairy and the supernatural without negating the more popular elements of romance that Epperly explores. Extending the definition of "romance" to include "poetry, classical myth, and the British fairy and folklore tradition" 22 reveals deeper resonances within Montgomery's work as it consistently points to other worlds of the fantastic, the folkloric, and the spiritual. This nuanced definition provides depth for L.M. Montgomery when she says that she holds "a passport to the geography of fairyland." 23 What Irene Gammel argues is true of Anne is true also of Montgomery: she blurs "the boundaries between inside and outside, life and art, human and nature, physical and metaphysical." 24 This biographical and narrative mixture of the fantastic and mimetic in Montgomery's writings invites us to look at the faërie and fantastic elements in Montgomery's realistic fiction, asking what she might be inviting the reader to imagine about real life.

Ultimately, exploring some fantastic elements in Montgomery's mimetic fiction reveals what kind of spirituality Montgomery invites readers into in her storied worlds. This exploration uses the following definition for the term "spirituality": what it means to "live, live fully and well" - a definition proposed by Eugene Peterson and one that works well in the current lived-experience trend among scholars of religion. As a community leader, diarist, poet, and fiction writer, Montgomery opens up numerous possible scholarly approaches to study lived experience in her fairy-tinged fiction. A brief survey of Montgomery scholarship shows movement from exploring religious and theological constructs in Montgomery's life and writing to more intimate and embedded concepts of spirituality. In a similar vein, this study suggests a model for considering Montgomery's spirituality that turns from religious structures and doctrinal beliefs to focus upon images of spiritual life-without negating the importance of institutional and doctrinal aspects of faith. These moments that provide models for "living, living fully and well" emerge from Montgomery's text as a narrative spirituality, embedded in story, character, and theme. In particular, this study argues that Montgomery's use of faërie motifs and evocations of fairyland provoke in the reader a more capacious and imaginative view of spiritual life. 
With a definition of spirituality and a model for turning to images of spiritual life in Montgomery's fiction, it is important to test the quality of Montgomery's preternatural passport by following her on a reader's pilgrimage into her work. Montgomery has written twenty novels and at least five hundred short stories. Given this extended bibliography and the limited nature of the study, and because for Montgomery reading held the "faithful old key to the gates of fairyland," $\underline{25}$ it is wise to stay as much as possible in her fiction. Narrowing in upon a single theme within a single text works to test the capacity for a narrative spirituality approach to Montgomery's fiction. Rainbow Valley, written at the close of World War I, 26 has an extensive discussion of the theme of heaven: in the kitchen conversations of the adults, in the philosophical debates of the children, and in the imagery used to describe Rainbow Valley. Whatever Montgomery might or might not be saying about a doctrine of heaven in Rainbow Valley, a close reading of the text shows that the character of the Valley as an imaginative fairyland is such that it invites a transformational understanding of spiritual life. By turning from doctrinal theology to spirituality in a close reading of faërie and supernatural elements in Rainbow Valley, the text reveals that this magical valley embodies a certain concept of heaven that informs earthly spirituality. This experiment in narrative spirituality concludes with suggestive possibilities of how this model of reading might enlighten other parts of Montgomery's fiction. 


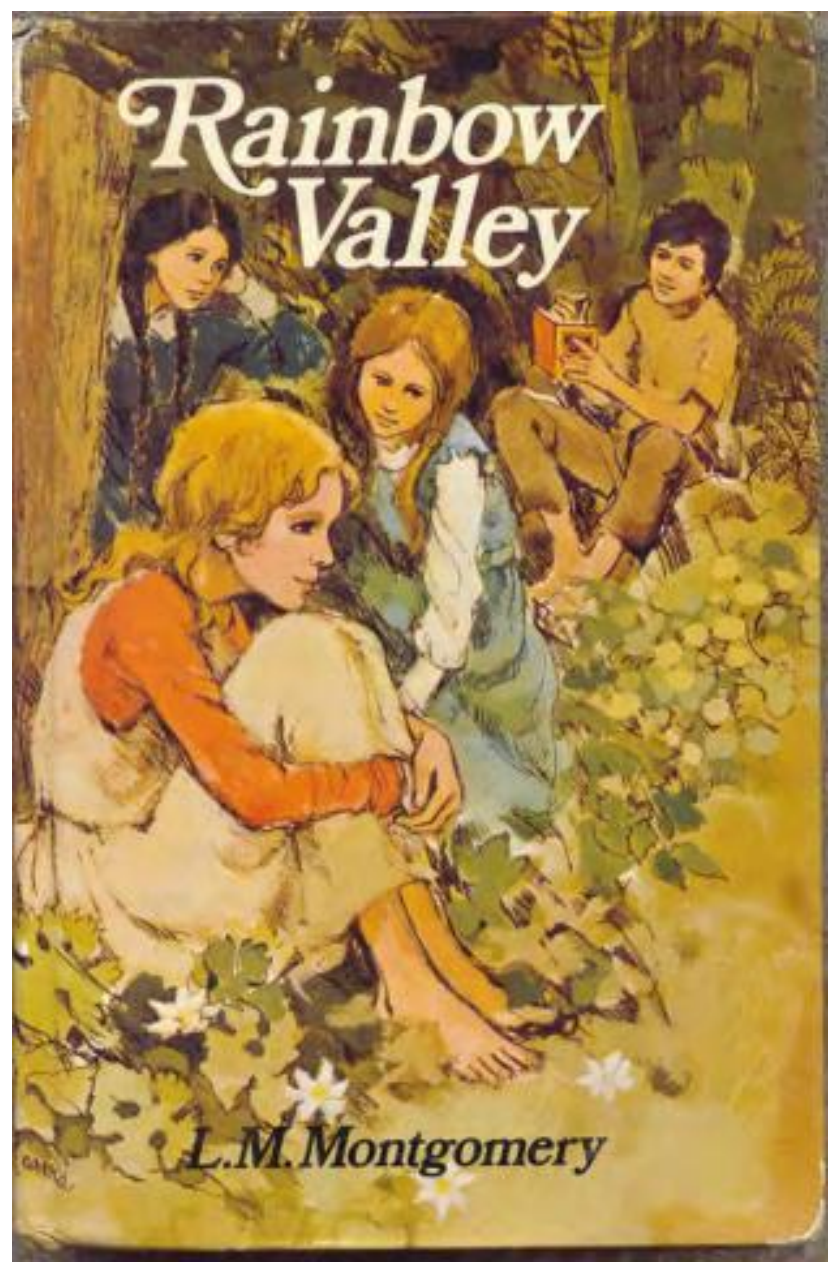

Book cover of Rainbow Valley. 1975. KindredSpaces.ca, 007 RV-AR.

This journey into Montgomery's fairylands will only give a few glimpses of what Montgomery is intimating for her readers; Montgomery's references to fey folk and their magical worlds are numerous and extensive. And any journey into faërie can be a perilous one. 27 But as someone who grew up on Prince Edward Island's north shore and who played in Montgomery's woods and fields, I know that the inhabitants of fairyland are very shy anyway. A glimpse is all we can ever expect to get, and looking out of the corner of our eyes is the proper approach to viewing fairy folk in their natural environment. It is fitting, then, that the turn to spirituality in story is also a kind of sideways glance, a looking away and a shy peek into other worlds. Jane Cowan Fredeman suggests that to understand what Montgomery is doing, we must "understand the distinction made in the novels between fantasy and those true glimpses beyond the veil which separate the real from an ideal world." 28 I think, by contrast, that if readers follow Montgomery into fairyland-on this particular journey, into Rainbow Valley-they will discover that in those enchanted woods and lanes 
that the veil between the worlds is torn away.

So if you are kindred spirits, if you are of the race that knows Joseph 29 and are kin to tribes of elfland, 30 if you are "that kind of people" that see rock people on the Island's north shores, 31 if you are of the "sect of dreamers" 32 or the "household of faith," 33 if you are "children of light" $34-$ by birthright or by any other means-or even if you are "next door to a perfect heathen" 35 with bright eyes and an open heart-if you have eyes to see-you are invited on this journey.

\section{The Turn to Spirituality}

As this is a quest to discern Montgomery's storied spirituality, it is important to pause and define what is meant by "spirituality" as a heuristic tool and to consider this particular approach to discerning how stories can reveal ideas about the spiritual life. As it is such a widely popular term, "spirituality" can be quite ambiguous. As diverse as definitions are, contemporary scholars in the study of Christian spirituality consistently use the words "lived," "life," or "living." 36 Eugene Peterson-a Presbyterian like Montgomery, though of a later generation-is one who embraces the mercurial nature of the term, including its popular understandings. While "spirituality" as a concept can be pulled in numerous directions, Peterson recognizes that it carries the meaning of "transcendence vaguely intermingled with intimacy." 37 


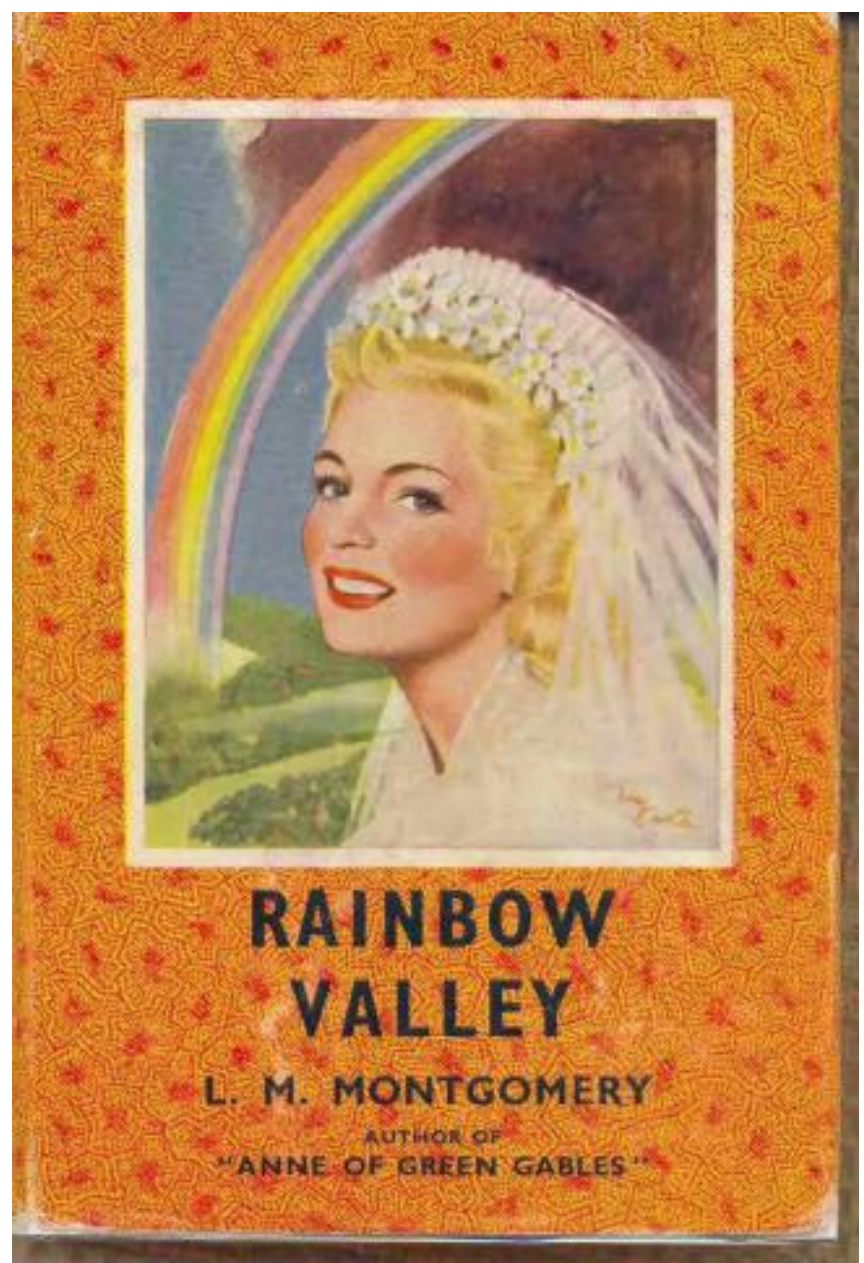

Book cover of Rainbow Valley. 1962. KindredSpaces.ca, 067 RV-H62.

This combination of heart-closeness and numinous awe is perhaps a way to capture Anne's rapturous response to natural beauty in her first drive from Bright River to Green Gables. She cries "Oh!" numerous times in response to scenes that transcend Matthew's sense of ordinary natural beauty. Anne wonders, slips into reverie, lifts her face in rapture, and sighs-struck dumb at one moment and speaking in constant delight the next. 38 When she sees "the Avenue" she declares, "It's the first thing I ever saw that couldn't be improved upon by imagination. It just satisfies me." 39 Anne places her hand upon her breast and speaks of the queer and funny yet pleasant ache she feels there. While Matthew cannot recall having this sort of heartache, Anne admits that she feels it often-and feels a similar thrill in first seeing the Lake of Shining Waters and silent reverence in first seeing Green Gables as they come around a bend in the path. Anne feels rapture in nature, in walks, in friendship, and in art. This rapture combines with reverence and a "thrill of joy" and a countenance that is only "half-earthly" as she meditates upon the Cuthberts' 
chromolithograph, “Christ Blessing Little Children." $\underline{40}$

Other of Montgomery's characters combine transcendence and intimacy in ways analogous to Anne, including the complex experience of the "flash" in the Emily trilogy.41 At the beginning of Emily of New Moon, the reader meets Emily as though she lives in a Garden of Eden-with Adam and Eve and an apple tree between them-and reading The Pilgrim's Progress. 42 Often enough, Emily walks "the straight and narrow path with Christian and Christiana," 43 but soon, she is running through the "spruce barrens" and "sloping pastures" in "a place where magic was made." 44 She is a character of "fairy birthright"-the kin of the elfin folk, her father calls her-and companion to all "the fairies of the white clover and satin catkins, the little green folk of the grass, the elves of the young fir-trees, sprites of wind and wild fern and thistledown." 45 She plays hide and seek with the Wind Woman as "there was a sudden rift in the curdled clouds westward, and a lovely, pale, pinky-green lake of sky with a new moon in it." $\underline{46}$ At the sight, Emily clasps her hands, turns her head upwards, and knows in her heart she must write about it. And then, "for one glorious, supreme moment, came 'the flash.'" 47 This short introduction brings together images of Emily's familial, literary, religious, faërie, magical, and mystical imagination. These moments then culminate in the indescribable experience of the flash, which Alice Munro calls a "moment of joy, of pure recognition" $\underline{48}$ and that Epperly says offers a "tantalizing glimpse of a world beyond, where beauty lives"-an experience of transcendence that "consecrates" Emily to her poetry. 49 In Anne's early encounters in Avonlea and Emily's experience of the flash, Montgomery describes well the intermingling of transcendent otherness and immanent experience that Peterson uses to define spirituality.

Thinking of both the transcendent and the intimate, the heavenly and mundane, Peterson argues that at its heart, spirituality is about "Living, living fully and well." 50 Throughout his writing on the spiritual life, Peterson consistently uses poetry and story to reveal the implications of living fully and well. Story, Peterson argues, "is the most natural way of enlarging and deepening our sense of reality, and then enlisting us as participants in it." $\underline{11}$ There is for Peterson something theologically essential about story: "Reality is story-shaped. The world is story-shaped. Our lives are story-shaped." $\underline{52}$ Theologian of literature Sallie McFague argues that "ordinary life and the transcendent" likewise meet in theology and in stories because they "are so intertwined that there is no way of separating them out." $\underline{33}$ There is an integrative reality to lived spirituality as it is tucked into the stories people tell one 
another and as it reveals itself in the books readers enjoy, potentially leading them into "a new way to live ordinary life." 54 This focus upon the emergent quality of spiritual life in story form is what I call a narrative spirituality.

Admittedly, "spirituality" as a term would have been somewhat foreign in Montgomery's context; there appears to be only one occurrence of the term in Montgomery's published fiction and poetry, a mocking note about a posture of goodness in Magic for Marigold.55 As spirituality is a concept that is instinctive to human expression, and as theologians like Peterson and McFague note links the nature of transcendence and intimacy in the telling of a tale, it is helpful to look at Montgomery's fiction through the lens of spirituality. As a heuristic tool, it is a useful way to consider Montgomery's understanding of what living a spiritual life well looks like as it is embedded within the worlds between realism and fantasy.

This study argues, then, for a turn from looking at Montgomery's structured thought about Christian doctrine or philosophical ethics to looking at what her fiction invites us to imagine about what it means to live fully and well. A brief survey of the scholarship also shows the narrative arc of Montgomery scholarship on the topic of religion captures this same turn to spirituality. A generation ago, scholars were invested in describing "The Religious Thought of L.M. Montgomery," to use Gavin White's title. It was the religious intellectual structure or theological belief that was the chief concern. Quoting White, Simone Nelles captures this approach from a reader's perspective:

An intense reading of Montgomery's private and public writings and the religious clues they contain brings one closer to the conviction that groping toward the realization of "a mature and balanced Christian faith" (White, "Religious" 84), [that is] stripped of fanaticism and an unctuous or exaggerated morality, and merging vital vision and expectant insight ....$\underline{56}$

From these studies of Montgomery's religious perspectives, there emerges an interest in the Puritan 57 and Scotch-Presbyterian 58 contexts of her thought. While these studies primarily look at the social aspect of religion, they have a sensitivity to the searching quality of Montgomery's lived experience. Both now and then, some scholars remain concerned to draw out threads of Montgomery's religious themes, specifically; $\underline{59}$ however, a critical turn to spirituality is evident in Julie Rae Golding Page's exploration of Montgomery's "Christian understanding of the sacramental imagination" $\underline{60}$ and Deirdre Kessler's interest in the "numinous, profoundly spiritual 
dimension" of Montgomery. 61 Similarly, Monika Hilder explores Montgomery's spirituality, demonstrating that Montgomery's "subversion of conventional religion" is itself an imaginative but rather conventional "exploration of faith." $\underline{62}$ In dialogue with Mary Rubio, Hilder suggests, "Like Anne's Romantic view of nature, Montgomery offers a dream of faith 'where we could drink of the wine of God's sunshine in his eternal communion that knows no restrictions or creeds.'" 63 In the vein of Hilder, recent studies seek to resolve the religious tensions in Montgomery's life and writings by shifting the conversation away from belief about doctrine or theological messaging in a didactic kind of way to the question of spirituality. This move works in that it allows for a more integrative conversation about the kind of Christian space Montgomery was negotiating.

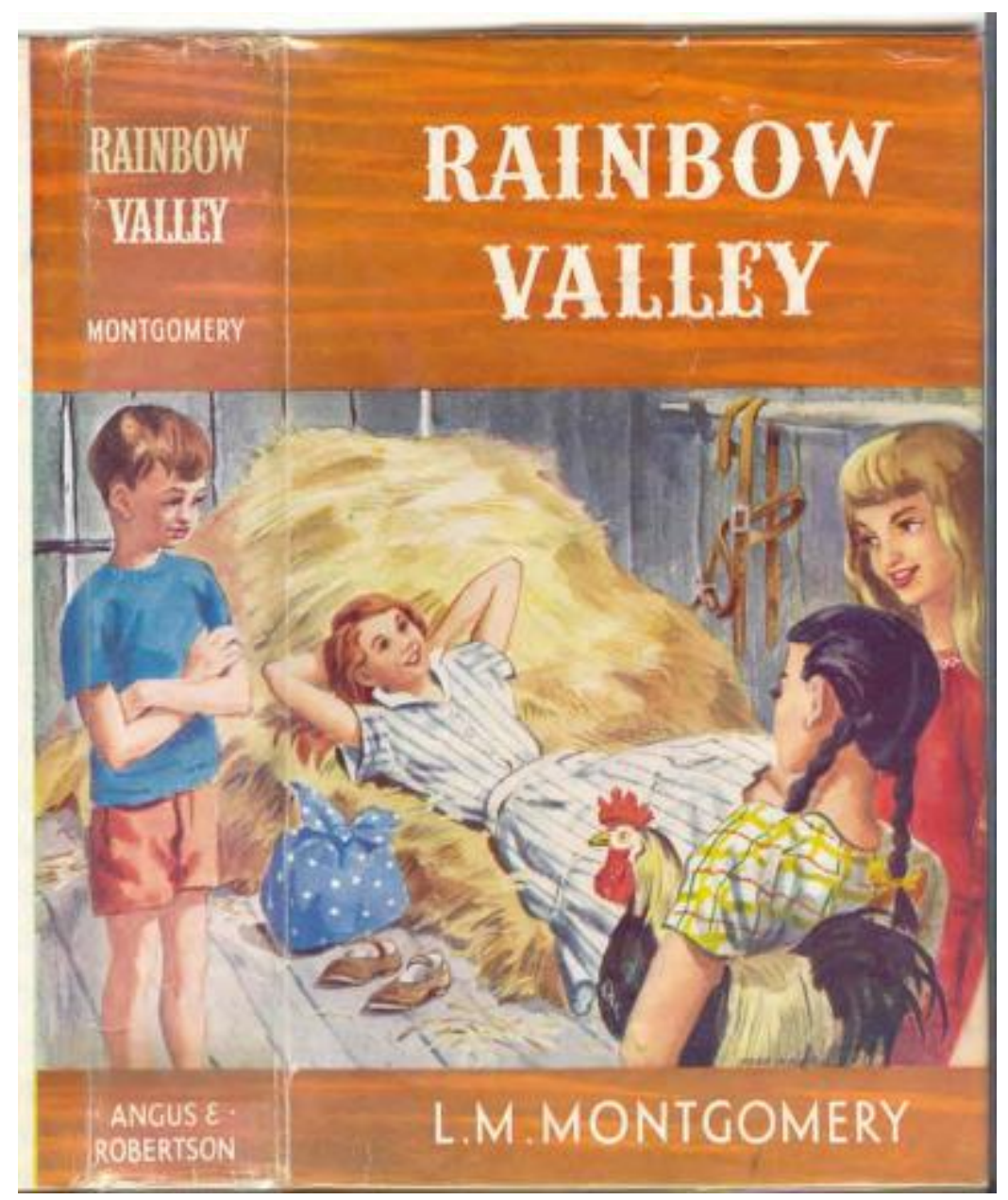

Book cover of Rainbow Valley. 1958. KindredSpaces.ca, 029 RV-AR.

More than that, though, turning to the question of spirituality instead of merely structured religious belief invites this question: what kinds of Christian life is 
Montgomery modelling, critiquing, rejecting, or experimenting with in her fiction? There is value in the debate about whether Montgomery is a "romantic pantheist," so Waterston; $\underline{64}$ or a nature worshipper, so Blair and Thompson; $\underline{65}$ or an "iconoclastic but ultimately orthodox" Christian, so Hilder.66 However, by turning to the question of what it means to live fully and well within a Christian theological frame of reference, Montgomery scholars and readers can avoid false choices sometimes offered in biographical studies. Whatever small rebellions and intellectual experiments Montgomery attempted, she remained within the Christian tradition-a tradition that throughout its history dialogues with and takes up paganisms, thoughtful questions, art, and literature. In looking at Montgomery's spirituality, my concern is not doctrinal specification. By asking readers to turn their heads slightly-as is the custom in fairy woods-I am asking what Montgomery's fiction reveals about the character of life from her point of view. I am curious about what the flavour of Montgomery's imaginative spirituality is-the "tang in the very air that inspire[s] the hearts" of character and reader. 67 What happens when readers tilt their heads slightly, moving from the question of structured belief to what it means to live fully and well? To see the difference-this turn from doctrinal religion to spirituality in order to catch the spiritual tang in the air-l will attempt an experimental close reading of Rainbow Valley, walking along the fairy paths of that magic valley to consider the topic of heaven. With the discoveries emerging from this journey into Rainbow Valley, I then make some suggestions about how this particular idea of spiritual life is infused in Montgomery's storied vision.

\section{Rainbow Valley as Embodied Heaven: An Illustrative Example of Spirituality}

\section{Rainbow Valley as a Faërie Wonderland}

Rainbow Valley, the first Anne novel to explore the lives of the Blythe children, begins with a kitchen conversation about heaven. The reference is not accidental, for Montgomery weaves heaven into the very fabric of Rainbow Valley as a faërie wonderland. Rainbow Valley is named by the romantic poet, Walter Blythe, and is a "fairy realm of romance." 68 Watched over by the "White Lady," a young silver birch, the children decorate a circle of interlocking spruce trees and maples with sleigh bells so that "every visitant breeze called out sudden fairy tinkles." $\underline{69}$ The language that attends to Rainbow Valley is indicative of its significance. Besides the language of natural beauty and old stories, Rainbow Valley is an earthbound fairyland made up of "Little, winding, fairy paths" $\underline{70}$ that lead to "all the airy, fairy places, full of 
weird, elfin grace." 71 The reader experiences the "gay voices and gayer laughter" of the children as it "echoed up and down the valley, dying away in elfin cadences among the trees." 72 And, of course, at night, the valley is an uncanny place where "some fairy parliament was being convened." 73 Some of this fairy language overlaps with the religious-such as conversation about the flower angel74 or when the children say grace over their caught, brought, and occasionally stolen meals. But as heaven is described above by Walter in similar terms as Rainbow Valley-and, indeed, the unruly Mary Vance equates Rainbow Valley and heaven directly $\underline{75}$-it is not a stretch to see that in Rainbow Valley the worlds of fairy and magic, nature and story combine to be an earthly representation of heaven.

It would be perhaps possible to read Rainbow Valley merely as a child's imaginative space writ large, a natural playhouse in the million-acre backyard of Montgomery's literary landscape. After all, as the novel continues and the children age, Jem joins the other children less and less so that he "seemed to be drifting away into grownup land." 76 The related question of aging and disappearing magic is a good one given Paul Irving's loss of ability to see his rock people in Anne of the Island77 and Emily's worry in Emily's Quest about losing the flash as she ages.78 However, this reduction of Rainbow Valley to a child's space would press the argument too far, as Rainbow Valley is also a critical place of recovery and awakening for adults like John Meredith and Rosemary West. Moreover, Montgomery never looks down upon "mere" childhood spaces, but treasures what children value and invests all her books with childhood glee, knowing that "of such is the kingdom of heaven" (Matt 19:14, KJV).79 Though looking on this novel's central adventures as an observer, Anne, moreover, continues to experience delights such as those of childhood.

Furthermore, she sees her imaginative traits channelled into her children, $\underline{80}$ and is unlike other people "because she never really grew up" and "just stayed a little girl inside." 81 Rainbow Valley encapsulates that kingdom of heaven principle of childlikeness within the fairy wilderness of the valley. 


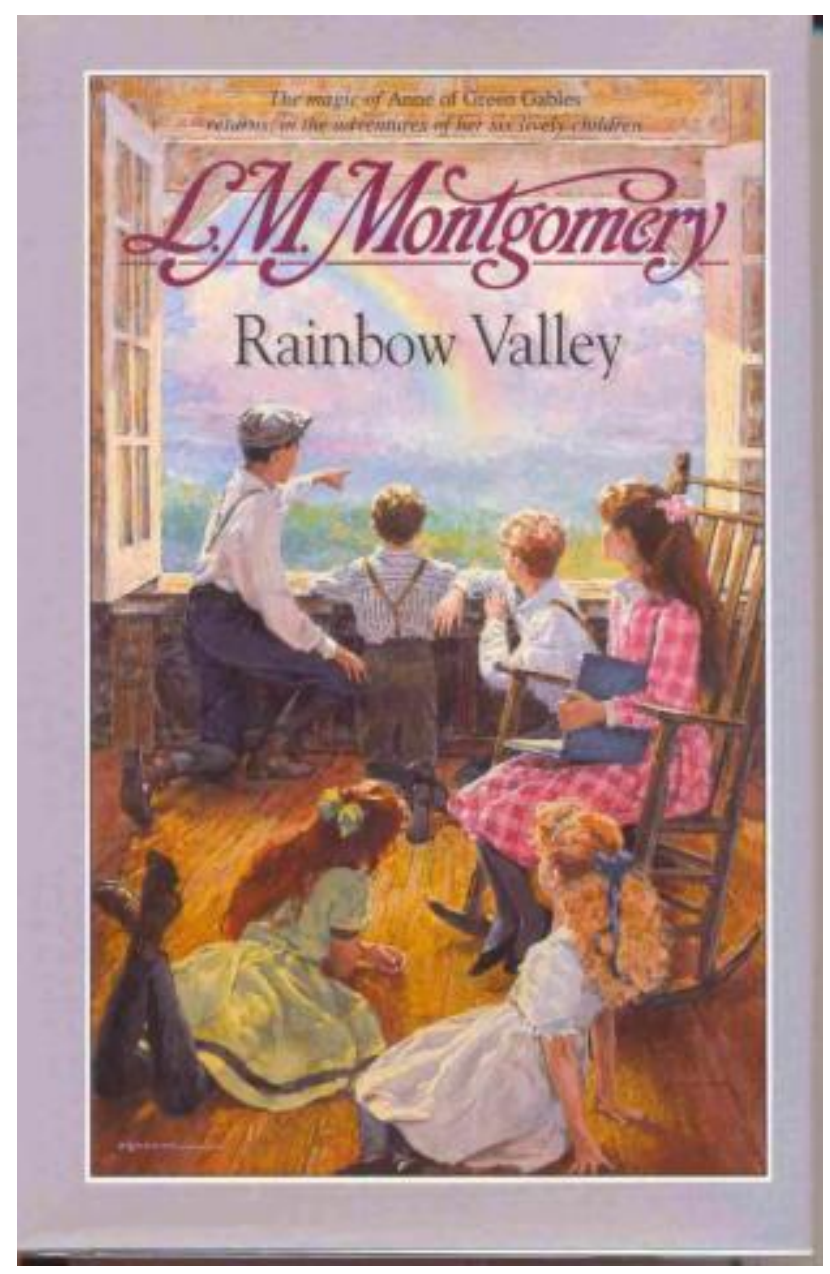

Book cover of Rainbow Valley. 1990. KindredSpaces.ca, 095 RV-MS.

The words used in the valley-rapture, $\underline{82}$ dream, $\underline{83}$ inspiration, $\underline{84}$ sacred, $\underline{85}$ immortal, $\underline{86}$ ethereal, 87 mystic, $\underline{88}$ charm, $\underline{89}$ and grace $\underline{90}$-fill the geographical place with images of faërie and faith. The "sanctum sanctorum of Rainbow Valley" 91 is a "wind-haunted and star-sentinelled ... dangerous, spell-weaving place," $\underline{92}$ both the energizing force behind the great Manse-Ingleside alliance and the setting for Walter's Pied Piper prophecy. Rainbow Valley is a rooted, earthly heaven, but a hint of paradise worth sharing, a place "which the mighty of earth might have envied" the children of their sanctuary. 93 In intermingling descriptions of otherness and closeness, Montgomery creates a magical and yet very real place that suggests a certain character of lived experience that is then clarified by the conversation about heaven in the valley.

\section{Heavenly Discourses in Rainbow Valley}


Drawing upon myriad traditions of wonder-magic, fairyland, myth, religion-the valley's "enchantment" is the spiritual background against which Montgomery presents a second way of thinking about heaven in Rainbow Valley, namely the "nice tasty discourse[s] on heaven" that arise.94 Rainbow Valley begins thinking about heaven because heaven is built into its essential framework. Susan Baker considers how everyone will be beautiful in the afterlife 95 and doubts that being a polyglot paves the way to heaven in any particular way. 96 The second chapter introduces the "beloved Rainbow Valley" and the report that "Little Jem said once he would rather go to Rainbow Valley than to heaven when he died," $\underline{97}$ a comment that is filled with the kind of impropriety that Susan always struggles with but that demonstrates the tangible link between heaven as a concept and Rainbow Valley as a sacred space.

Others in the text wrestle with questions of what heaven may be like. In a friendly debate with Susan Baker and Anne Blythe, Miss Cornelia contests the "everlasting rest doctrine, "98 arguing that she wants "to bustle round in heaven the same as here," pitching in on whatever "celestial substitute for pies and doughnuts" exists in the great beyond.99 Susan objects when someone imagines out loud that they will laugh and cry when greeting lost loved ones in heaven. When pressed, she relents a little: "I might go so far as to say that you both would have to smile now and again, but I can never admit that there will be laughing in heaven. The idea seems really irreverent, Mrs. Dr. dear." 100 While this discourse could be dismissed as mere "kitchen talk," the conversation reveals important theological points that rhyme with the discoveries of the children discussed below. As the children will contemplate the revelation that heaven has trees and natural beauty, so the adults discover that there is creativity in heaven and good work to do- "something that has to be made "101 There is laughter and enjoyment in the kingdom of heaven, something that Anne suspects, even as a next door-to-a-heathen child under the spiritual tutelage of Marilla. 102

Remembering the kingdom of heaven principle noted above, that children have a certain ability to discern spiritual things, it is the children who lead the spiritual way in the Anne books-even if the adults are the official teachers, ministers, and mentors. Montgomery wants Anne to remain childlike in Rainbow Valley, even if her character recedes to the background in this later book. It is important, then, to attend to what children have to say of heaven. 
In a childhood Rainbow Valley discourse where the proposed location of hell as a place somewhere in New Brunswick is rejected as possibly unbiblical, the runaway Mary Vance is taught the popular misunderstanding of Christian eschatology that good people go to heaven and bad people go to hell to burn eternally in fire. Later, the conversation in Rainbow Valley turns again to heaven. Walter has been reading of Coleridge's heaven, where "There were gardens bright with sinuous rills." 103 Mary challenges the idea of trees in heaven, having heard it was just streets and streets. After Nan Blythe's assertion that she and her mother couldn't live in eternity without trees, Walter adds to his vision of a wooded heaven with an image that draws together the natural, the biblical, and the fantastic:

"There are cities, too," said the young dreamer, "splendid cities-coloured just like the sunset, with sapphire towers and rainbow domes. They are built of gold and diamonds-whole streets of diamonds, flashing like the sun. In the squares there are crystal fountains kissed by the light, and everywhere the asphodel blooms-the flower of heaven." 104

While the children agree that heaven is grander even than the main street in Charlottetown, a dispute breaks out about how they might spend their time in that great paradisal estate. Diana Blythe asserts that heaven is filled with fun, but Mary has picked up some of Miss Cornelia's austerity and rejects the possibility.

Suggesting that "Bible language is figurative" on this point, Nan opines that "heaven will be just like what you'd like it to be." 105

\section{Turning Our Heads: Rainbow Valley as Spirituality in the Character of Heaven}

The conversations in Rainbow Valley echo those in Anne of Avonlea, offering a vision of heaven to challenge popular imaginations of heaven, such as Miss Cornelia's feeling that the idea of laughter in heaven is irreverent, and that people will spend all their time simply looking "solemn and holy."106 Moreover, these conversations work together with the heaven imagery discussed in the previous section. Creatively spaced, nature-filled, and laughter-soaked, Rainbow Valley reveals both in the fairyland images and the various tasty discourses that heaven is a place where imagination is realized. It is difficult to know whether Rainbow Valley is heaven-like, or heaven is Rainbow Valley-like. Perhaps even this is an unhelpful distinction. Remembering the experiment of turning from the question of doctrinal clarification to lived spirituality, what does the multi-layered use of story invite readers to think 
about living fully and well? Whatever challenge Montgomery may have been offering to public doctrine-and her vision would not have shocked orthodox Christian imaginative writers about heaven like Dante Alighieri, C.S. Lewis, or George MacDonald - the character of Montgomery's embodied heaven, both in the setting of Rainbow Valley and in the theological musings of her characters, goes some distance in giving shape to the character of the Christian life.

After all, Rev. Meredith spends much of the novel quietly struggling with the fact that he is in danger of being so heavenly bound that he is no earthly good.107 At a critical point, as Meredith "paced up and down the room, reflecting deeply on the immortality of the soul," he remains reflectively "unaware that Jerry and Carl were playing leap-frog hilariously over the flat stones in that abode of dead Methodists." 108 As Faith Meredith and her siblings find themselves in trouble without even meaning to be mischievous, Meredith "was in the study thinking of his sermon and other heavenly things." 109 In the end, though, Rev. Meredith and all the characters are grounded with the idyllic Rainbow Valley as a model of life and a space for encounter-encounters of friendship, love, and ideas about life-rather than merely a place of escape. In Rainbow Valley, Rev. Meredith discovers himself and falls into love; Mary Vance finds a loving and structured home; the Manse children get a proper mother and the hope of a decent meal; and Walter Blythe finds his courage, his poetry, and the chilling destiny he must face in World War I. 


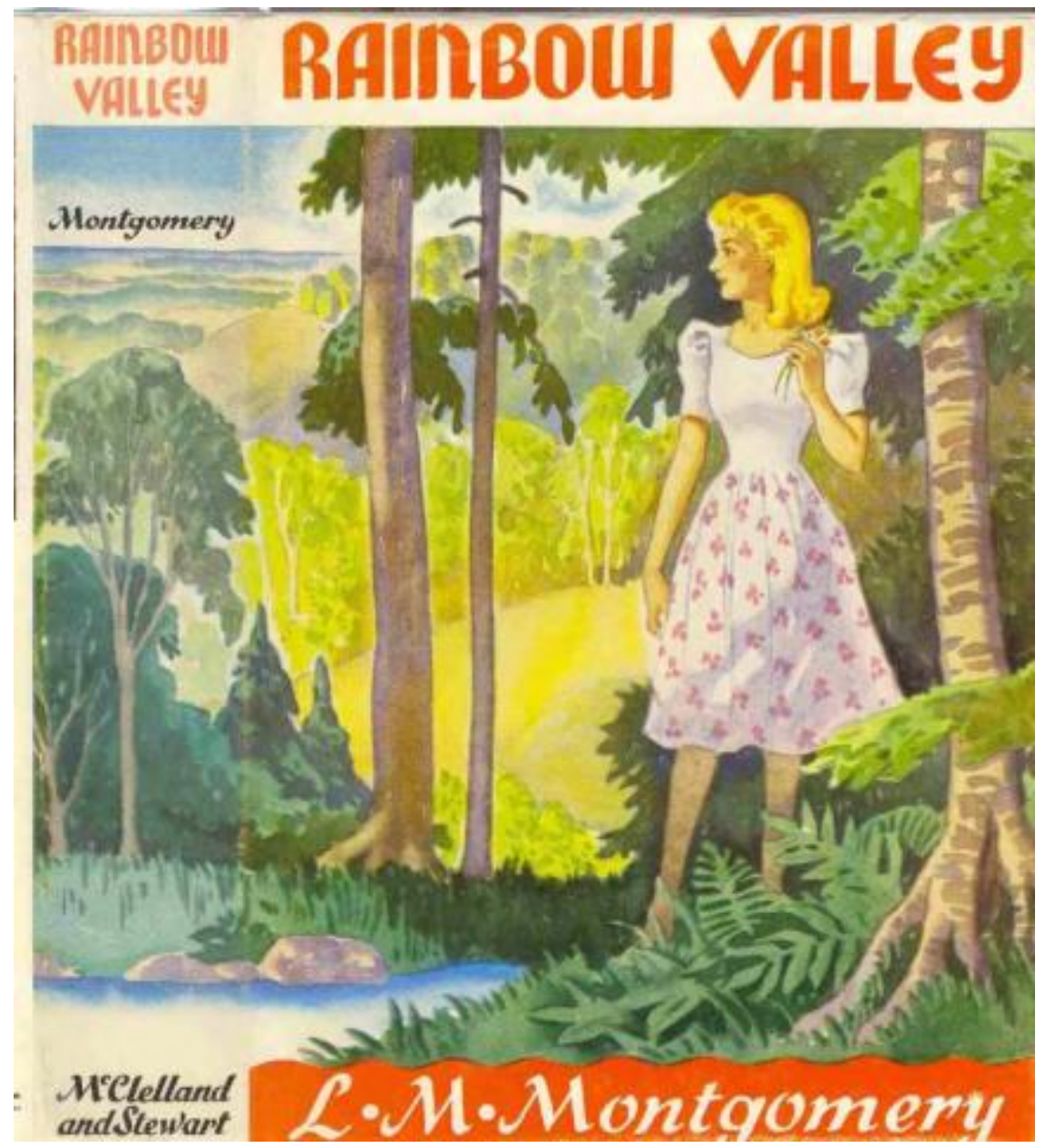

Book cover of Rainbow Valley. 1923. KindredSpaces.ca, 149 RV-MSC.

With a little imagination, the spiritual implications are evident. It is not merely heaven that will be useful, creative, joyful, and beautiful, but that Christian spirituality should also evoke these characteristics in everyday life. There is little doubt that L.M. Montgomery would describe a good spiritual life as useful, creative, joyful, and beautiful. The "tang" of Montgomery's heaven is what the "tang" of life should be for those who aim at heaven, and Rainbow Valley as a faërie wonderland gives the reader a picture of a spiritual life.110 There is a continuity between earthly life and heavenly existence in Montgomery's imagination so that the two places are mutually interdependent in the life of the spirit. From Eugene Peterson's perspective, Rainbow Valley teaches us what it means to live, live fully and well-or, in Sallie McFague's terms, to discover a new way to live ordinary life. The aptly named Manse child, Faith, draws these realities together when she shocks a dour widow on the church porch by declaring that the "world isn't a vale of tears, Mrs. Taylor. It's a world of laughter." 111 Whatever Montgomery might have thought of 
Christian theology as a public discipline, Faith's critique is a profound statement about lived spirituality with Rainbow Valley-the opposite of a dour, rugged, defeatist "vale of tears" that becomes a "vale of laughter"-as a model.

Children and childlikeness are important to the perspective of the novel, and the children, especially, encapsulate the lesson. The conclusion of their Wordsworthian Rainbow Valley discussion of heaven is telling. Mary Vance, who has experienced an earthly hell in her short young life, responds to Nan Blythe's idea that heaven will be as the people who go there imagine it by saying that she would like heaven "to be just like Rainbow Valley." 112 This is the "on earth as it is in heaven" Lord's Prayer principle that confirms Anne's instinctive and innocent approach to faith in Anne of Green Gables. "The world looks like something God had just imagined for His own pleasure," Anne declares in Anne of Green Gables, 113 no doubt feeling as Montgomery herself did on a twilit autumnal walk: "tingling with the strange ... sweet life of the spirit." $\underline{114}$

When walking away from the Rainbow Valley discussion about heaven, one of the Manse children notes that they should know more about heaven than Walter should, since they are the minister's children. Once again, Faith makes the poignant link: "We know just as much, but Walter can imagine." 115 I believe this is the imaginative invitation to readers of Montgomery's fiction, infused as it is with ideas about spiritual life. In using the setting and conversations of Rainbow Valley to collapse the false binary of knowledge and imagination, Montgomery offers an integrated approach to Christian spirituality that readers can see modelled throughout her books.

\section{Conclusion: Embodied Spirituality in the Character of Anne}

This reading of Rainbow Valley shows the kind of pilgrimage into fairyland Montgomery invites readers into. As Walter uses his theological imagination, readers of Montgomery can intuitively understand how it works. In a Rainbow Valley that embodies heaven, Montgomery is able to integrate her two ways of seeing-seeing as poetry and as prose-working on a distinction Anne makes in Anne of Avonlea: "I suppose that's how it looks in prose. But it's very different if you look at it through poetry." 116 With this epistemological distinction, Montgomery suggests that truth is an interrelated conversation between "knowing" and "imagining" in Rainbow Valley 117-what C.S. Lewis calls bringing together the two hemispheres of his mind, the poles of reason and romanticism. 118 Lewis had an unrestricted view of the word 
"romance," listing seven kinds of romanticism beyond stories about falling in love. 119 This essay is about opening up the word "romance" for Montgomery, experimenting imaginatively about what it means, in Peterson's terms, to "live, live fully and well." Montgomery brings together the language of faith, mysticism, Arthurian romance, chivalry, stage play, fairy tale, classical myth, pagan folklore, fantasy, and romantic poetry.

Montgomery then pours those combined fantastic realms into the people and places of her works. Just as Rainbow Valley is embodied heaven, Walter Blythe embodies "Tennysonian chivalry" 120 and is in his own person a singular response to the poets of the Great War. Moving out from Rainbow Valley, Emily Byrd Starr embodies the numinous vocation of writing with Jane Eyre-like perspicuity, which I elsewhere compare with C.S. Lewis' idea of Sehnsucht, a philosophy of Joy.121 Visualizing, in turn, the major characters of the Anne books, one can imagine how each represents a flawed-but-suggestive spirituality. Behind Rachel Lynde's legalism is a sense of rugged duty and fierce loyalty. Reverend and Mrs. Allan display a different pathway with their robust and generous ministry. Captain Jim brings wit and story together with unwavering ethics and tender love. Davy the conscience-ridden rebel, Dora the unimaginative and obedient soul, Abel Blair the authentic hypocrite, and cautious Marilla, whose headaches occur most frequently on Sunday-viewed from the lens of spirituality, each of these characters offers a perspective on living fully and well. 


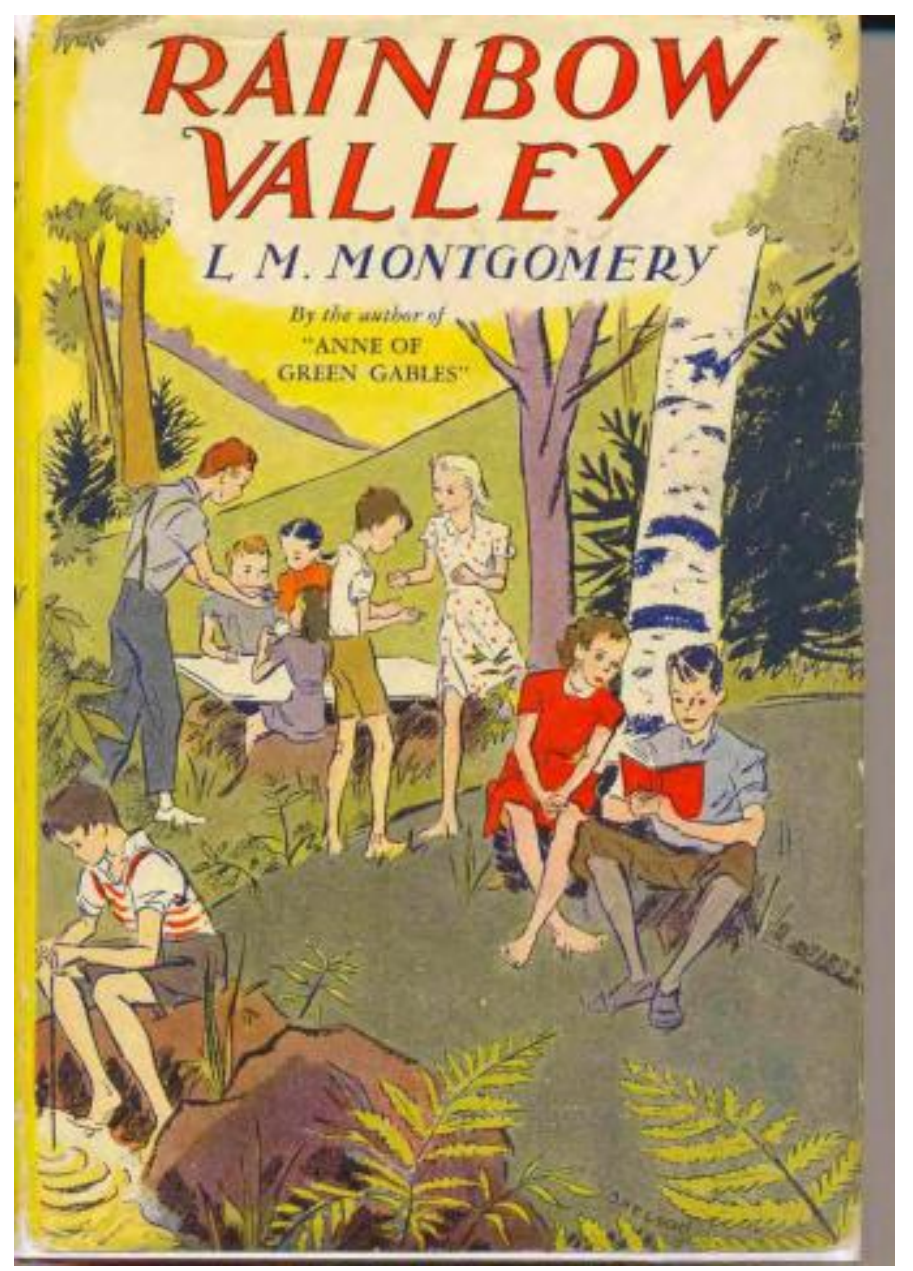

Book cover of Rainbow Valley. 1938. KindredSpaces.ca, 180 RV-GD.

Experimentally, tentatively, I have argued that by following Montgomery into the fairylands in her realistic fiction, we can learn something about how to live fully and well. To cross this temenos, to move beyond the threshold into Montgomery's fairyland, we do not need a Narnian wardrobe. Walter and his siblings do not enter an ethereal rabbit hole or tangible door in the air to find their way into Rainbow Valley; it is their imaginations that are key. Anne does not arrive in Avonlea through Platform 93/4 but takes the 5:30 train to Bright River and rides home to Green Gables in Matthew's buggy, tugged along by the sorrel mare. In the way that Montgomery has constructed her fictional universe, even in Rainbow Valley where Anne is not at the front of the narrative, Anne herself is the "woods between the worlds," and she passes this imaginative inheritance to the children of Rainbow Valley. Anne is the "wicket gate" into a land of wonder, the portkey into imagination, the guide to and embodiment of elfin lands. Anne carries fairyland in her own being, for, as Epperly has noted, the "mixture of magic and fact" in Montgomery's fiction "is personified in 
Anne herself." 122 Thus, in following Montgomery into her realistic fiction, as in Anne's imaginative redrawing of Avonlea and Four Winds Harbour, the expectant reader experiences a transformed world-a transformation that comes, in Gillian Thomas's words, "by the exercise of her 'imagination.'” 123

Considering the way that Montgomery layers her work with poetic, folkloric, and fairy textures, Blair and Thompson claim that Montgomery "invokes 'the gods of the Golden Age' ... associated with a lost pastoral world of poetry, classical myth, and the British fairy and folklore tradition, always nostalgically recalled and imaginatively recreated through hints and faint survivals." 124 They are correct about Montgomery's storied intertextuality but limited if the "recalling" from the past is about nostalgia. To journey with Montgomery into fairyland is to encounter integrated possibilities of what it means to live, to live fully and well. In following Montgomery in imagination, readers sail with her "over storied seas that wash the distant shining shores of 'faery lands forlorn,' where lost Atlantis and Elysium lie, with the evening star for pilot, to the land of Heart's Desire." 125 And in those imaginative adventures, readers can then return to everyday realities with a deeper perspective about the character of spiritual life. In Montgomery's varied characters, in the magical imagination of Anne or the poetic instincts of Walter, and in Rainbow Valley itself, there are embodied examples that invite readers into a storied spirituality of joy, laughter, imagination, possibility, creativity, hard work, rigorous duty, and "belief in magical surprises within the everyday world." 126 This is, after all, the very principle of fairyland: "for things seen pass away, but the things that are unseen are eternal." 127

About the Author: Brenton Dickieson (MCS, Regent College; Ph. D., University of Chester) is a writer, researcher, and teacher originally from New Glasgow, Prince Edward Island. He grew up playing in L.M. Montgomery's Cavendish backyards but did not really discover her books until adulthood. He teaches literature and spirituality at a number of universities and has been teaching at UPEI since 2006. His research considers how the creation of storied worlds contributes to conversations about spirituality, theology, and cultural criticism. His popular blog, www.aPilgrimInNarnia.com, explores the intersections of faith, fantasy, and fiction. Brenton is married to a superstar kindergarten teacher, Kerry, and they parent a red-headed teenager son, Nicolas, who is working to become a rock legend. 
Please see my article, "C.S. Lewis's Theory of Sehnsucht as a Tool for Theorizing L.M. Montgomery's Experience of 'The Flash,'" in The Faithful Imagination: Papers from the 2018 Francis White Ewbank Colloquium on C.S. Lewis and Friends, Taylor University, edited by Joe Ricke and Ashley Chu, pp. 144-65. I have also written a number of L.M. Montgomery blog posts on www.apilgriminnarnia.com. Posts include, "In an Age of Literary Groups, L.M. Montgomery Was Alone" ( https://apilgriminnarnia.com/2018/06/07/groups-alone/) and "The Peculiar Background to L.M. Montgomery's 'The Alpine Path'" ( https://apilgriminnarnia.com/2018/05/31/alpine-path/).

Banner image derived from Dolina Teczy. 1990. KindredSpaces.ca, 347 RV-Polish.

- 1 Sullivan, Anne of Green Gables: The Sequel.

- 2 Montgomery, Als 89.

- 3 Montgomery, $A A 157$.

- 4 Montgomery, AGG 144.

- $\underline{5}$ Montgomery, AGG 88-89.

- 6 Montgomery, RV 85.

- 7 Montgomery, RV 14.

- 8 Montgomery, RV 222.

- 9 Montgomery, RV 77.

- 10 Montgomery, RV 77.

- 11 Montgomery, BAQ 209.

- 12 Montgomery, BAQ 371.

- 13 I am using "faërie" as a distinctive term to image the perilous and romantic realms of fairy tales and popular romance. Historically, this "fairyland" is variously spelled as faërie, faerie, faery, and fairy. An example of the interchangeable nature of the term is in the relevant use of Keats's "faery lands forlorn" in "Ode to a Nightingale" (see note 28). Montgomery references the lands forlorn as "faerie" in "The Life-Book of Uncle Jesse" (Along the Shore, 37), as "faëry" in Anne of the Island (9), and as "fairy" in Anne's House of Dreams (26). John Keats himself uses "fairy" in the manuscript of the poem "Ode to a Nightingale," but it is anthologized as "faery" (Keats 821).

- 14 Montgomery, BAQ 397.

- 15 Montgomery, BAQ 397. 
- 16 Montgomery, SJ 1 (4 Apr. 1899): 235.

- 17 Epperly, Fragrance 11.

- 18 Epperly 10. Epperly's chapter on Rainbow Valley, "Heroism's Childhood," is, in particular, focused upon an interpretation of the novel under a consideration of chivalric romance. See also Alan R. Young, "Romance and the Experience of War."

- 19 See Epperly 109-10.

- 20 See Epperly 147, 162-67.

- 21 Epperly xxxi.

- 22 Blair and Thompson, "The Mood" 132.

- 23 Montgomery, AP 47.

- 24 Gammel, “Embodied” 229.

- 25 Montgomery, SJ 1 (23 Aug. 1901): 262.

- 26 Indeed, completed on the Christmas eve following the armistice agreement, see SJ 2 (26 Dec. 1918): 278.

- 27 One thinks of Anne quoting Keats in Anne's House of Dreams (26): "A magic casement opening on the foam / Of perilous seas in fairy lands forlorn." See Epperly 80.

- 28 Fredeman, "The Land" 61.

- 29 A category revealed by Miss Cornelia and used by Anne to consider who might be a kindred spirit. The Rev. Meredith and the Manse children, in Anne's estimation, "belong to the race that knows Joseph" (Montgomery, RV).

- 30 Montgomery, ENM 5.

- 31 See Anne of Avonlea, where Paul and Anne discuss being "that kind of people" who both knew "'How fair the realm / Imagination opens to the view,' and both knew the way to that happy land. There the rose of joy bloomed immortal by dale and stream; clouds never darkened the sunny sky; sweet bells never jangled out of tune; and kindred spirits abounded. The knowledge of that land's geography ... . 'east o' the sun, west o' the moon' . . . is priceless lore, not to be bought in any market place. It must be the gift of the good fairies at birth and the years can never deface it or take it away. It is better to possess it, living in a garret, than to be the inhabitant of palaces without it" (Montgomery, AA 127-28).

- 32 Montgomery, RV 21.

- 33 Montgomery, AHD 38.

- 34 Montgomery, AA 53.

- 35 Montgomery, AGG 52. 
- $\underline{36}$ For example, see Aumann, "Spiritual Theology" 22; Callen, Authentic Spirituality 17; Chan, Spiritual Theology 15-39; Downey, Understanding Christian Spirituality 146; Foster and Helmers, Life with God 7; Sheldrake, Spirituality and Theology 35; Vandenbroucke, "Spirituality and Spiritualities" 51-52; and most articles in Holder, The Blackwell Companion to Christian Spirituality, specifically pp. 1-5 of Arthur Holder's "Introduction" and Sandra M. Schneiders's chapter, "Approaches to the Study of Christian Spirituality," 15-33.

- 37 Peterson, Christ Plays 27.

- 38 Montgomery, AGG 17, 21.

- 39 Montgomery, AGG 18.

- 40 Montgomery, AGG 56.

- 41 I attempt to delineate aspects of Emily's transcendent-intimate ecstasies in "C.S. Lewis's Theory of Sehnsucht as a Tool for Theorizing L.M. Montgomery's Experience of 'The Flash.'"

- 42 Montgomery, ENM 2-3.

- 43 Montgomery, ENM 3.

- 44 Montgomery, ENM 6.

- 45 Montgomery, ENM 3, 6.

- 46 Montgomery, ENM 6.

- 47 Montgomery, ENM 7.

- 48 Munro, "Afterword" 359.

- 49 Epperly 151.

- 50 Peterson, Christ Plays 29.

- 51 Peterson, Christ Plays 24.

- 52 Peterson, Eat This Book 62.

- 53 McFague, Speaking in Parables 45.

- 54 McFague 45.

- 55 Montgomery, MM 127-28.

- 56 Nelles, Pilgrimages 105.

- 57 See Klempa, Passionate Blood.

- 58 Rubio, "Scottish-Presbyterian Agency."

- 59 For example, Sorfleet's 2003 study of pagan resonances or Blair and Thompson's 2016 ecotheological exploration.

- $\underline{60}$ Golding Page, Kindred iii; 30-33; 120-34.

- 61 Kessler, "L.M. Montgomery" 234.

- 62 Hilder, “'That Unholy Tendency'” 34. 
- $\underline{63}$ Hilder 7, quoting SJ 1:240.

- 64 Waterston, “Lucy Maud Montgomery" 15.

- 65 Blair and Thompson 134.

- 66 Hilder 35.

- 67 Montomery, AGG 190.

- 68 Montgomery, RV 14.

- 69 Montgomery, RV 15.

- 70 Montgomery, RV 14.

- 71 Montgomery, RV 136-37.

- 72 Montgomery, RV 141.

- 73 Montgomery, RV 198.

- 74 Montgomery, RV 19.

- 75 Montgomery, RV 77.

- 76 Montgomery, RV 161.

- 77 Montgomery, Als 151-55.

- 78 Montgomery, EQ 158. For the "passing" of childhood see Epperly, especially 71; note that Epperly's treatment of "romance" throughout the study includes the struggle with aging.

- 79 Again, as an example, see Anne's exultation before the picture "Christ Blessing Little Children" in Anne of Green Gables (56). Mary E. Doody Jones notes the thread that is taken up in later Wordsworthian Romanticism, where Montgomery inherits a tradition that "views the child as a 'seer blest,' gifted with spiritual knowledge" (Barry, Annotated Anne, 426).

- 80 Especially Walter. See Montgomery, RV 77.

- 81 Montgomery, RV 25.

- 82 Montgomery, RV 17.

- $\underline{83}$ Besides references to the "House of Dreams" where Jem was born, "dream" and its cognates are used more than fifty times in Rainbow Valley.

- 84 Faith, in particular, is prone to having moments of "inspiration." See $R V 25$, 70, 107-08, 176.

- 85 Used variously, including the epigraph and the title of chapter 27. "Sacred" is used of the biblical world ( $R V 51)$, of the spiritual centre of the human heart in relational connection ( $R V 86,143$ ), and of Rainbow Valley itself ( $R V$ 85).

- $\underline{86}$ Immortal is used throughout for life in heaven, as well as to describe an encounter at the sacred spot of Rainbow Valley ( $R V$ 85) as well as Walter's poetic longings ( $R V$ 17-18).

- 87 Montgomery, $R V 86$. 
- $\underline{88}$ Used of Walter's piper that Di can almost believe is in the valley (RV 55), as well as of Rosemary West's encounter in Rainbow Valley ( $R V$ 89), and of duskveiled natural beauty ( $R V$ 193).

- $\underline{89}$ Used of people and places, it is used also of the timid, electric grace of falling in love ( $R V$ 89) and for the peculiar "charm of Rainbow Valley" ( $R V$ 93) and the circle of fellowship the children had forged in Rainbow Valley ( $R V$ 223).

- 90 Beyond references to meal-time prayer and bodily grace (or community disgrace), Rainbow Valley is described as the most beautiful and dreamlike of "all the airy, fairy places, full of weird, elfin grace" (RV 136-137). Its magical charm even penetrate Rev. Meredith's academic reverie: "The ethereal beauty of the asters in the moonlight, the glimmer of the little spring, the soft croon of the brook, the wavering grace of the brackens all wove a white magic round John Meredith" (RV 86).

- 91 Montgomery, RV 25.

- 92 Montgomery, RV 87.

- 93 Montgomery, RV 19.

- 94 Montgomery, RV 119.

- 95 Montgomery, $R V 3$.

- 96 Montgomery, $R V 6$.

- 97 Montgomery, RV 5.

- $\underline{98}$ Montgomery, RV 103.

- 99 Montgomery, RV 103-04.

- 100 Montgomery, RV 104.

- 101 Montgomery, RV 104.

- 102 Montgomery, AGG 42.

- 103 Coleridge, “Kubla Khan," line 8.

- 104 Montgomery, RV 77.

- 105 Montgomery, RV 77.

- 106 Montgomery, RV 104.

- 107 Montgomery, RV 27.

- 108 Montgomery, RV 21.

- 109 Montgomery, RV 178.

- 110 Montomery, AGG 190.

- 111 Montgomery, RV 22.

- 112 Montgomery, RV 77.

- 113 Montgomery, AGG 144.

- 114 Montgomery, SJ 1 (20 Nov. 1906): 324. 
- 115 Montgomery, RV 77.

- 116 Montgomery, $A A 264$.

- 117 Montgomery, RV 77.

- 118 Lewis describes the "hemispheres of my mind" in his spiritual autobiography, Surprised by Joy, especially chapter 11 . These two hemispheres are pictured in the North and South sides of the road in Lewis's allegorical mappa mundi of his The Pilgrim's Regress; see also Kreeft, C.S. Lewis 4-15.

- 119 Lewis, Pilgrim's Regress 208-09.

- 120 Epperly 10.

- 121 See my “C.S. Lewis's Theory of Sehnsucht and L.M. Montgomery's Experience of 'The Flash': A Conversation on Vocation and the Numinous."

- 122 Epperly 31.

- 123 Thomas, "The Decline" 40.

- 124 Blair and Thompson 132; contra Sorfleet, "From Pagan to Christian" 176-77.

- 125 Montgomery, Als 9.

- 126 Epperly 74.

- 127 Montgomery, Als 9.

Back to top

\section{Article Info}

Copyright: Brenton D. G. Dickieson, 2020. This work is licensed under a Creative Commons Attribution 4.0 International License (Creative Commons BY 4.0), which allows the user to share, copy and redistribute the material in any medium or format and adapt, remix, transform and build upon the material for any purpose, even commercially, PROVIDED the Licensor is given attribution in accordance with the terms and conditions of the CC BY 4.0.

Peer reviewed

Yes

\section{Works Cited:}

Aumann, Jordan, O.P. “Spiritual Theology by Fr. Jordan Aumann, O.P." Internet Archive, 
Barry, Wendy E., Mary E. Doody Jones, and Margaret Anne Doody, editors. The Annotated Anne of Green Gables by L.M. Montgomery, Oxford UP, 1997.

Blair, Kirstie, and William V. Thompson. "The Mood of the Golden Age: Paganism, Ecotheology and the Wild Woods in L.M. Montgomery's Anne and Emily Series." Literature and Theology, vol. 30, no. 2, 2016, pp. 131-47.

Callen, Barry. Authentic Spirituality. Baker Books, 2001.

Chan, Simon. Spiritual Theology: A Systematic Study of the Christian Life. InterVarsity P, 1998.

Coleridge, Samuel Taylor. "Kubla Khan." The Norton Anthology of English Literature: Volume 2, 5th ed., edited by M.H. Abrams. W.W. Norton and Company, 1962, p. 354.

Dickieson, Brenton D.G. "C.S. Lewis's Theory of Sehnsucht as a Tool for Theorizing L.M. Montgomery's Experience of 'The Flash.'" The Faithful Imagination: Papers from the 2018 Francis White Ewbank Colloquium on C.S. Lewis and Friends, Taylor University, edited by Joe Ricke and Ashley Chu, Winged Lion P, 2019, pp. 144-65.

Downey, Michael. Understanding Christian Spirituality. Paulist P, 1997.

Epperly, Elizabeth R. The Fragrance of Sweet-Grass. U of Toronto P, 1992.

Foster, Richard J., and Kathryn A. Helmers. Life with God: Reading the Bible for Spiritual Transformation. HarperOne, 2008.

Fredeman, Jane Cowan. "The Land of Lost Content: The Use of Fantasy in L.M. Montgomery's Novels." L.M. Montgomery: An Assessment, edited by John Robert Sorfleet, Canadian Children's P, 1976, pp. 60-70.

Gammel, Irene. "Embodied Landscape Aesthetics in Anne of Green Gables." The Lion and the Unicorn, vol. 34, no. 2, Apr. 2010, pp. 228-47.

Golding Page, Julie Rae. Kindred to the Spirit: A Christian Perspective on the Imagination as Portrayed in L.M. Montgomery's "Anne of Green Gables" Series. M.A. Thesis, Regent College, 2000. 
Hilder, Monika B. “'That Unholy Tendency to Laughter': L. M. Montgomery's Iconoclastic Affirmation of Faith in Anne of Green Gables." Canadian Children's Literature/Littérature canadienne pour la jeunesse, vol. 113-14, 2004, pp. 34-55.

Holder, Arthur. The Blackwell Companion to Christian Spirituality. Blackwell, 2005.

Keats, John. "Ode to a Nightingale." The Norton Anthology of English Literature: Volume 2, 5th ed., edited by M.H. Abrams. W.W. Norton and Company, 1962, pp. 819-22.

Kessler, Deirdre. "L.M. Montgomery and the Creation of Prince Edward Island." L.M. Montgomery and Canadian Culture, edited by Irene Gammel and Elizabeth Epperly, U of Toronto P, 1999, pp. 229-34.

Klempa, Mary-Margaret. Passionate Blood, Puritan Conscience: An Intertextual Study of the Private and Public Works of L.M. Montgomery. M.A. Thesis, Concordia U, 1998.

Kreeft, Peter. C.S. Lewis: A Critical Essay. Eerdmans, 1969.

Lewis, C.S. The Pilgrim's Regress: Wade Annotated Edition. Edited by David C. Downing. Eerdmans, 2014.

---. Surprised by Joy. Harcourt, Brace and Co., 1956.

McFague, S. Speaking in Parables: A Study in Metaphor and Theology. Fortress P, 1975.

Montgomery, L.M. Along the Shore: Tales by the Sea. McClelland and Stewart, 1989.

---. The Alpine Path: The Story of My Career. Fitzhenry and Whiteside, 1974.

---. Anne of Avonlea. Seal Books, 1908.

---. Anne of Green Gables. 1908. Seal Books, 1996.

---. Anne of the Island. 1915. Seal Books, 1996.

---. Anne's House of Dreams. 1917. Seal Books, 1996.

---. The Annotated Anne of Green Gables. Edited by Wendy E. Barry, Margaret Anne Doody, and Mary E. Doody Jones, Oxford UP, 1997. 
---. The Blythes Are Quoted. Viking Canada, 2009.

---. Emily of New Moon. 1923. Seal Books, 1983.

---. Emily's Quest. 1927. Seal Books, 1983.

---. Magic for Marigold. 1925. McLelland and Stewart, 1929.

---. Rainbow Valley. 1919. Seal Books, 1987.

---. The Selected Journals of L.M. Montgomery. Edited by Mary Rubio and Elizabeth Waterston, Oxford UP, 1985-2004. 5 vols.

Munro, Alice. Afterword. Emily of New Moon, by L.M. Montgomery, McClelland and Stewart, 2007, pp. 357-61.

Nelles, Simone. Pilgrimages in a Land of Penumbra: A Critical Reading of the Religious Theme and Its Complex Variations in Lucy Maud Montgomery's Approaches toward Faith. M.A. Thesis, Johannes Gutenberg University of Mainz, 1998.

"Ode to a Nightingale." The British Library, https://www.bl.uk/works/ode-to-anightingale.

Peterson, Eugene H. Christ Plays in Ten Thousand Places: A Conversation in Spiritual Theology. Eerdmans, 2005.

---. Eat This Book: A Conversation in the Art of Spiritual Reading. Eerdmans, 2006.

Rubio, Mary Henley. “L.M. Montgomery: Scottish-Presbyterian Agency in Canadian Culture." L.M. Montgomery and Canadian Culture, edited by Irene Gammel and Elizabeth Epperly, U of Toronto P, 1999, pp. 89-105.

Sheldrake, Philip. Spirituality and Theology: Christian Living and the Doctrine of God. Orbis, 1998.

Sorfleet, John. "From Pagan to Christian: The Symbolic Journey of Anne of Green Gables." Windows and Words: A Look at Canadian Children's Literature in English, edited by Aida Hudson and Susan-Ann Cooper, U of Ottawa P, 2003, pp. 175-183.

Sullivan, Kevin, director. Anne of Green Gables: The Sequel. A Kevin Sullivan Production, 1987. 
Thomas, Gillian. "The Decline of Anne: Matron vs. Child." Canadian Children's Literature/Littérature canadienne pour la jeunesse, vol. 1, no. 3, 1975, pp. 37-41.

Vandenbroucke, Francois. "Spirituality and Spiritualities." Spirituality in Church and World, edited by Charles Duquoc, Paulist P, 1965, pp. 45-60.

Waterston, Elizabeth. "Lucy Maud Montgomery: 1874-1942." L.M. Montgomery: An Assessment, edited by John Robert Sorfleet, Canadian Children's P, 1976, pp. 9-26.

White, Gavin. "The Religious Thought of L.M. Montgomery." Harvesting Thistles: The Textual Garden of L.M. Montgomery, Essays on Her Novels and Journal, edited by Mary Henley Rubio, Canadian Children's P, 1994, pp. 84-88.

Young, Alan R. “L.M. Montgomery's Rilla of Ingleside (1920): Romance and the Experience of War." Myth and Milieu: Atlantic Literature and Culture 1918-1939, edited by Gwendolyn Davies, Acadiensis P, 1993, pp. 95-122. 